\title{
射出成形データ解析ソフト DATAFLOW (データフロー)
}

\section{1.はじめに}

弊社の射出成形データ解析ソフトDATAFLOW は，す でに多くのユーザーから好評をもって迎えられている。そ の中で，ユーザーからとくに要望の多かった，画面表示の 日本語化がこのたび完成したので（図 1), その仕様, 機 能を紹介したい。

\section{2. 仕 様}

- 対応 OS : Windows 95/98, NT

入力最大チャンネル数：16または 32 （ただし 32 チャン ネル版は，ハード一体の別仕様)

- 入力電压範囲 : $0 \sim \pm 10 \mathrm{~V}$

・最大サンプリング速度：100 kHz（1チャンネルのみ使 用の場合)

\section{3. 機 能}

- 最大値, 最小値, 平均値, 標準偏差の計算

- 最大值, 最小值, 平均值, 許容差, ボックス, 積分值, 射出仕事量など 14 種類のモニタ方式

・波形，数值，管理図，バーグラフ，良否ランプの表示

・異なるデータファイルから波形を呼び出して重ね描きが 可能
・オプションのインタフェースボックス $2853 \mathrm{~A}$ (図 2) を 使えば, チャージアンプモジュール, 電圧アンプモジュー ル，アンプ制御モジュールなどを自由に組み合わせて挿 入可能

\section{4. . 今後の展開}

これまでの英語版の販売もかなりの数量にのぼり，ユー ザーからのフィードバックが色々と得られている.たとえ ば，機能を絞り込んだ低価格バージョンへの要望も強い。 こうしたユーザーの意見を尊重し，今後さらに使いやすく 価格の低いバージョンを用意すべく検討を重ねていく所存 である。

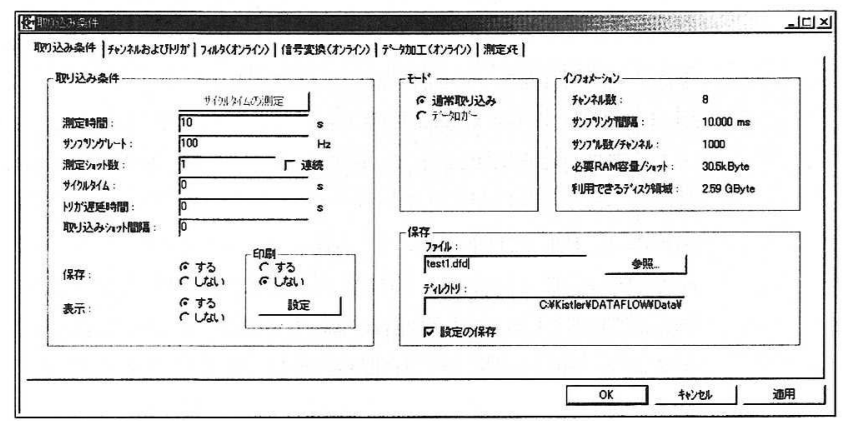

図 1 取込設定画面

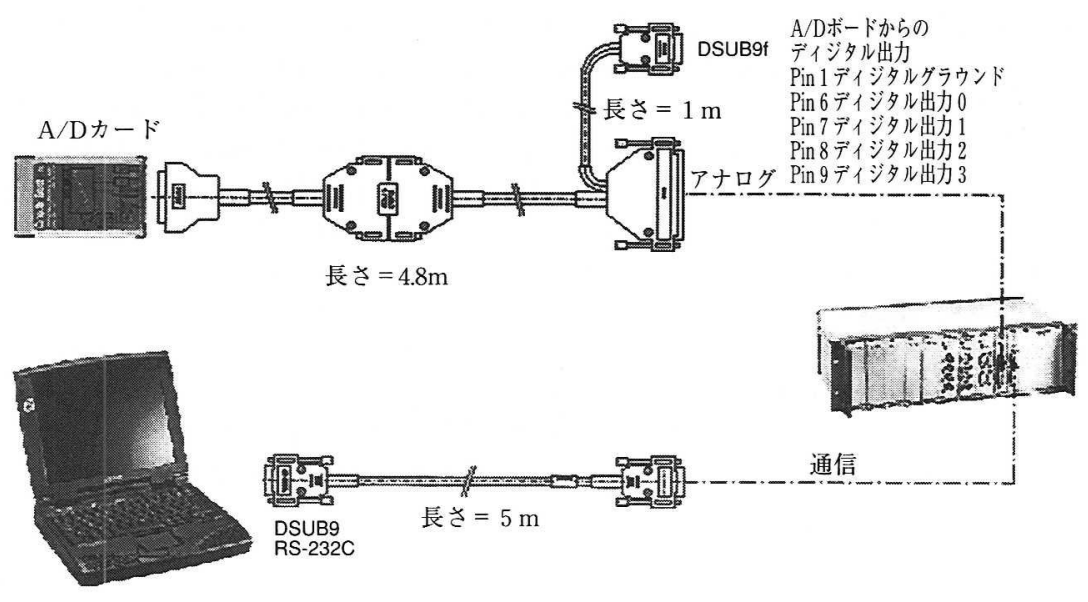

図 2 システム構成例

〈問合せ先〉

日本キスラー株

東京都港区芝大門 2-7-5 MT ビル（邓 105-0012）

TEL (03) 3578-0271 FAX (03) 3578-0278

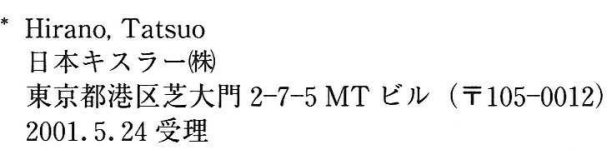

2001. 5.24 受理 